American Journal of Pharmacology and Toxicology 6 (2): 68-75, 2011

ISSN 1557-4962

(C) 2011 Science Publications

\title{
Reversal of Dexamethasone Depressant Action in Wound Healing by Ficus Benghalensis L. Roots
}

\author{
${ }^{1}$ Krishna Murti and ${ }^{2}$ Upendra Kumar \\ ${ }^{1}$ Department of Pharmacology,Singhania University, Rajasthan India \\ ${ }^{2}$ Department of Pharmaceutical Chemistry, \\ College of Pharmacy, Azamgarh, Uttar Pradesh India
}

\begin{abstract}
Problem statement: Ficus benghalensis is widely used plant world wide traditionally as well as scientifically. It has a wide uses in various medical ailments. As a part of pharmacological evaluations, we have carried out wound healing activity specially in dexamethasone depressed healing conditions. Approach: Wound healing activity was established by two medels namely incision and excision. Results: The roots of Ficus benghalensis clearly reverted the antihealing in presence of dexamethasone treated animals. It happened through increase in breaking strength in incision model and increase in percentage wound contraction and reduction in period of epithelialization. Conclusion: Presence of various chemical constituents in the roots of Ficus benghalensis specially saponins, flavanoids, taannins and alkaloids were responsible for antagonizing the antihealing effect of dexamethasone treated animals.
\end{abstract}

Key words: Ficus benghalensis, wound healing, dexamethasone treated, incision wound, excision wounds, wound models, drug administration, Analysis Of Variance (ANOVA), wistar rats

\section{INTRODUCTION}

Wound is a breach in the normal tissue continuum, resulting in a variety of cellular and molecular sequelae. The basic principles of optimal wound healing which include minimizing tissue damage, debriding nonviable tissue, maximizing tissue perfusion and oxygenation, proper nutrition and moist wound healing environment have been recognized for many years (Pierce and Mustoe, 1995). A number of drugs ranging from simple non-expensive analgesics to complex and expensive chemotherapeutic agents administered in the management of wound affect healing either positively or negatively (Prasad and Rao, 1995). Aspirin, indomethacin, cytotoxic agents and immunosuppressant have been proved experimentally to affect healing negatively (Lee, 1968; Rao et al., 1991; Raju and Kulkarni, 1986).

Ficus benghalensis (Moraceae, Mulberry family) is commonly known as Banyan tree or Vata or Vada tree in Ayurveda. There are more than 800 species and 2000 varieties of Ficus species, most of which are native to the old World tropics. Ficus benghalensis a remarkable tree of India sends down its branches and great number of shoots, which take root and become new trunk. This tree is considered to be sacred in many places in India. Earlier glucoside, 20-tetratriaconthene-2-one, 6heptatriacontene-10-one, pentatriacontan-5-one, beta
sitostirol-alpha-D-glucose and meso-inositol have been isolated from the bark of Ficus benghalensis (Subramanian and Misra, 1978; CSIR, 1952). Leaves contain crude protein $9.63 \%$, crude fibres-26.84, CaO2.53 and Phosphorus-0.4\%. It yields latex containing Caoytchoue (2.4\%), Resin, Albumin, Cerin, Sugar and Malic acid. It is used in Ayurveda for the treatment of Diarrhea, Dysentery and piles, (Mukherjee et al., 1998; Husain et al., 1992) teeth disorders, (Aiyer, 1960) Rheumatism, skin disorders like sores, (Warrier et al., 1996) to boost immune system, (Gabhe et al., 2006) as a hypoglycemic (Shrotri and Aiman, 1960; Deshmukh et al., 1960; Augusti, 1975; Augusti et al., 1994). The extracts of Ficus benghalensis were also reported to inhibit insulinase activity from liver and kidney (Achrekar et al., 1991). Fruit extracts exhibited antitumor activity in the potato disc bioassay (Mousa et al., 1994). Two flavonoid compounds, viz. 5, 7-dimethyl ether of leucopelargonidin 3-0-alpha-L rhamnoside and 5, 3,-dimethyl ether of leucocyanidin 3-0-alpha-D galactosyl cellobioside were obtained from the bark of $F$. benghalensis evaluated for anti-oxidant activity in hyperlipidemic rats Daniel et al., 1998). It was also found to inhibit the lipid peroxidation. (Shukla et al., 2004). Various extracts of Ficus benghalensis was screened for its anti-allergic and anti-stress potential in asthma by milk induced leucocytosis and milk induced eosinophilia (Taur et al., 2007). Other species of Ficus

Corresponding Author: Krishna Murti, Department of Pharmacology,Singhania University, Rajasthan India Tel: +91-9328832853 
viz. Ficus inspida (Amorin et al., 1999). Ficus carica, (Iqbal et al., 2001).

Till today, there are not many agents which are able to successfully overcome the antihealing effect of corticosteroids. Dexamethasone is a very potent antiinflammatory Glucocorticoids used in organ transplantation and skin allograft (Tripathi, 2004). Glucocorticoids are known to suppress wound healing (Paul and Thomas, 1968). Dexamethasone treatments strongly interfere with both the synthesis and degradation of type I and type III collagen (Oishi et al., 2002). It is also a potent transcriptional inhibitor of human type VII collagen promoter activity in dermal fibroblasts, which leads to decreased anchoring of fibril formation (Gras et al., 2001). Significant inhibition of growth of pathogenic microorganisms was observed in vitro by traditional drugs like Ficus benghalensis, Azardicta indica and Annona squamosa. No scientific evidence was available for the wound healing activity on the roots of Ficus benghalensis; therefore the present research was undertaken.

\section{MATERIALS AND METHODS}

Collection and Authentification of plant: Roots of Ficus benghalensis was collected from the adjoining areas of Modasa (Gujarat, India). The collection was done in the month of August, 2010. It has been authenticated by Dr. M.K. Jangid, Associate Professor, Department of Botany, Hemchandra North Gujarat University, Gujarat, India by carrying out microscopic and macroscopic characteristics and voucher specimen was deposited in the institute for future reference.

Preparation of the root extract: Dried and coarsely $500 \mathrm{~g}$ powdered roots of Ficus benghalensis L. were extracted with $90 \%$ (v/v) ethanol in soxhlet apparatus for $36 \mathrm{hrs}$ and aqueous extract was prepared by using maceration technique of extraction. Filter the filtrate. The filtrate was concentrated on water bath using petridish. The temperature was maintained at $50{ }^{\circ} \mathrm{C}$. The semisolid extract was dried and weighed. The semisolid mass (brown colour) was obtained and used for further phytochemical study and animal activity.

Acute toxicity study

Acute toxicity study was done in rats weighing between 150-200 g. Rats were fasted overnight. They were divided into 5 groups of two animals each. The ethanolic extract of Ficus benghalensis was administered orally through the feeding tube to the pair of rats of each group in ascending and widely spaced doses viz. 10, 30, 100, 300, $1000 \mathrm{mg} \mathrm{kg}^{-1}$. The animals were observed continuously for $2 \mathrm{~h}$ and then occasionally for further $4 \mathrm{~h}$ and finally overnight mortality was recorded. No signs of toxicity were observed even with $1000 \mathrm{mg} \mathrm{kg} \mathrm{kg}^{-1}$ of Ficus benghalensis. So the dose of the extract chosen for the study was $100 \mathrm{mg} \mathrm{kg}^{-1}$ which is corresponding to the 1/10th of the maximum tolerated dose $\left(1000 \mathrm{mg} \mathrm{kg}^{-1}\right)$ (Ghosh, 1971).

Drugs and their administration: Ketamine injection was obtained from Neon Laboratories Limited (Mumbai, India), Dexamethasone was obtained from Zydus Alidac (Ahmedabad, India). For oral administration, a suspension of aqueous and ethanol extract (8\%) was prepared using $2 \%$ gum acacia. The drugs were administered once a day from day 1 and continued till the completion of the models.

Wound Healing Models: Animals and grouping: Wistar albino rats of either sex weighing between 180 and $200 \mathrm{~g}$ were obtained from Jay Research Foundation, Vapi. The study was approved by the Institutional Ethics Committee for animal experimentation VBTCP (VBTCP/IEAC/10/12/31), Umrakh and all the procedures on animals were carried out as per CPCSEA guidelines, India. The animals were acclimatized to standard laboratory conditions of temperature $\left(22 \pm 3^{\circ} \mathrm{C}\right)$ and maintained on 12:12 h light: dark cycle. They were provided with regular rat chow (VRK laboratory animal feed) and distilled water ad libitum.

Group 1:Control group treated with simple saline orally (p.o)

Group 2:Dexamethasone treated group intraperitoneally (i.p)

Group 3:Aqueous extract of Ficus benghalensis L. + Dexamethasone $(p . o+i . p)$

Group 4:Ethanolic extract of Ficus benghalensis L. + Dexamethasone $(p . o+i . p)$

Incision wound model: All animals were anaesthetized before wound creation and two paravertebral long incisions were made through the skin at the distance of about $1.5 \mathrm{~cm}$ from midline on each side of the depilated back of rat. The both edges kept together and stitched with black silk surgical thread (no. 000) and a curved needle (no. 11). The continuous threads on both wound edges were tightened for good closure of the wound. After stitching, extract ointment and standard ointment were applied daily up to 9 days; when wounds were cured thoroughly the sutures were removed on the day 
Am. J. Pharm. \& Toxicol., 6 (2): 68-75, 2011

9 and tensile strength of cured wound skin was measured using tensiometer.

Excision wound model: Excision wounds were created by excising a circular piece $\left(500 \mathrm{~mm}^{3}\right.$ in area) of full thickness skin from the dorsal interscapular region. Wound contraction was monitored by measuring wound area, planimetrically, on alternate days till the wounds were completely healed. This was expressed as percentage of wound contraction. Time taken for complete epithelialization was noted by recording the days required for fall of scab leaving no raw wound behind.

Drug administration: Animals bearing a given wound were divided into 4 groups of 6 animals each. First group of animals received distilled water and served as control, Second group received dexamethasone $\left(0.17 \mathrm{mg} \mathrm{kg}^{-1} \mathrm{im}\right)$, third group received $100 \mathrm{mg} \mathrm{kg}^{-1}$, orally of aqueous extract of Ficus benghalensis and dexamethasone (0.17 $\left.\mathrm{mg} \mathrm{kg}^{-1} \mathrm{im}\right)$ and the fourth group received ethanolic extract of Ficus benghalensis $(100 \mathrm{mg} / \mathrm{kg}$, orally) and dexamethasone $\left(0.17 \mathrm{mg} \mathrm{kg} \mathrm{kg}^{-1} \mathrm{im}\right)$. The Ficus benghalensis(aqueous and ethanolic) extract was given daily, dexamethasone on alternate days from day 0 to the day of complete healing or the 10th postoperative day, according to the wound healing model.

Statistical analysis: Results were Analysed by one Way Analysis Of Variance (ANOVA) using post hoc dunnet's test and p-value $<0.05$ was considered significant.

\section{RESULTS}

Phytochemical analysis: On preliminary phytochemical screening the extract showed that the roots of Ficus benghalensis L. contain saponins, tannins, alkaloids and flavanoids while other constituents like amino acids, carbohydrate was absent (Table 1). Further the presence of these chemical constituents was confirmed by HPTLC analysis as $R_{f}$ values for standard, aqueous and ethanolic extract respectively are shown in Plates and tables. The $3 \mathrm{D}$ images contains First with Standard, secondly with aqueous and lastly with ethanolic extract peaks. (Fig. 1-4 and Table 1-5).

Incision wound model: A significant decrease in wound breaking strength in dexamethasone alone treated group was observed as compared to control group.
Table 1: Phytochemical analysis of extract of ficus benghalensis

\begin{tabular}{ll}
\hline Phytochemical & Confirmation \\
\hline Amino acids & - \\
Carbohydrates & - \\
Tannins & + \\
Alkaloids & + \\
Flavonoids & + \\
Saponins & + \\
\hline
\end{tabular}

Table 2: Tannins

\begin{tabular}{|c|c|c|c|c|c|c|}
\hline \multicolumn{3}{|c|}{ Gallic acid } & \multicolumn{2}{|c|}{$\begin{array}{l}\text { Ficus bengalensis } \\
\text { (Alcoholic) }\end{array}$} & \multicolumn{2}{|c|}{$\begin{array}{l}\text { Ficus bengalensis } \\
\text { (Aqueous) }\end{array}$} \\
\hline Peak & $\mathrm{R}_{\mathrm{f}}$ & AREA & $\mathrm{R}_{\mathrm{f}}$ & AREA & $\mathrm{R}_{\mathrm{f}}$ & AREA \\
\hline$\overline{1}$ & 0.34 & 1571.7 & 0.17 & 1581.2 & 0.30 & 1864.0 \\
\hline 2 & 0.42 & 12246.8 & 0.42 & 18372.5 & 0.38 & 32540.9 \\
\hline 3 & 0.55 & 13677.0 & & & & \\
\hline
\end{tabular}

Table 3: Alkaloids

\begin{tabular}{llrlr}
\hline & \multicolumn{2}{l}{ Ficus bengalensis (Alcoholic) } & Ficus bengalensis & (Aqueous) \\
Peak & $\mathrm{R}_{\mathrm{f}}$ & AREA & $\mathrm{R}_{\mathrm{f}}$ & AREA \\
\hline 1 & 0.04 & 22219.1 & 0.05 & 11863.3 \\
2 & 0.13 & 4283.0 & 0.17 & 220.8 \\
3 & 0.18 & 6652.7 & 0.30 & 1091.1 \\
4 & 0.30 & 2595.6 & 0.36 & 728.2 \\
5 & 0.41 & 171.4 & 0.41 & 168.5 \\
6 & 0.44 & 1814.3 & 0.45 & 266.9 \\
7 & 0.58 & 493.4 & 0.49 & 350.2 \\
8 & 0.62 & 914.3 & 0.61 & 1224.9 \\
9 & 0.67 & 652.4 & 0.67 & 2507.5 \\
10 & 0.72 & 3582.2 & 0.75 & 425.0 \\
11 & 0.81 & 4417.8 & 0.81 & \\
\hline
\end{tabular}

Table 4: Flavanoids

\begin{tabular}{|c|c|c|c|c|c|c|}
\hline \multirow[b]{2}{*}{ Peak } & \multicolumn{2}{|c|}{ Rutin } & \multicolumn{2}{|c|}{$\begin{array}{l}\text { Ficus bengalensis } \\
\text { (Alcoholic) }\end{array}$} & \multicolumn{2}{|c|}{$\begin{array}{l}\text { Ficus bengalensis } \\
\text { (Aqueous) }\end{array}$} \\
\hline & $\mathrm{R}_{\mathrm{f}}$ & AREA & $\mathrm{R}_{\mathrm{f}}$ & AREA & $\mathrm{R}_{\mathrm{f}}$ & AREA \\
\hline 1 & 0.01 & 2231.6 & 0.02 & 7848.1 & 0.05 & 7553.9 \\
\hline 2 & 0.07 & 4429.9 & 0.06 & 13485.6 & 0.20 & 415.0 \\
\hline 3 & 0.18 & 3762.5 & 0.32 & 7998.6 & 0.25 & 1373.7 \\
\hline 4 & 0.23 & 6077.3 & 0.46 & 2067.4 & 0.60 & 173.5 \\
\hline 5 & 0.28 & 62162.2 & 0.58 & 644.6 & 0.65 & 200.0 \\
\hline 6 & 0.47 & 7114.3 & 0.66 & 164.7 & 0.77 & 1009.5 \\
\hline 7 & 0.55 & 8088.2 & 0.79 & 1798.3 & 0.84 & 807.7 \\
\hline 8 & 0.94 & 6217.7 & & & 0.94 & 5399.7 \\
\hline
\end{tabular}

Table 5: Saponins

\begin{tabular}{lllll}
\hline & $\begin{array}{l}\text { Ficus bengalensis } \\
\text { (Alcoholic) }\end{array}$ & & $\begin{array}{l}\text { Ficus bengalensis } \\
\text { (Aqueous) }\end{array}$ \\
Peak & $\mathrm{R}_{\mathrm{f}}$ & AREA & $\mathrm{R}_{\mathrm{f}}$ & AREA \\
\hline 1 & 0.19 & 1160.3 & 0.09 & 4408.3 \\
2 & 0.29 & 4748.5 & 0.24 & 1821.6 \\
3 & 0.59 & 393.3 & 0.30 & 1835.2 \\
4 & 0.68 & 409.5 & 0.33 & 1372.7 \\
5 & 0.89 & 351.0 & 0.54 & 3569.3 \\
6 & 0.94 & 2483.4 & 0.63 & 4390.3 \\
7 & & & 0.80 & 5144.3 \\
8 & & & 0.88 & 376.3 \\
9 & & & 0.96 & 638.7 \\
\hline
\end{tabular}


Am. J. Pharm. \& Toxicol., 6 (2): 68-75, 2011

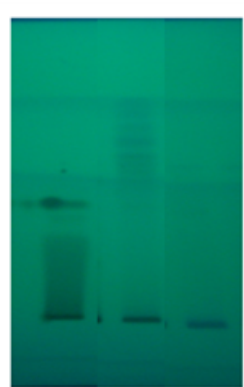

(a)

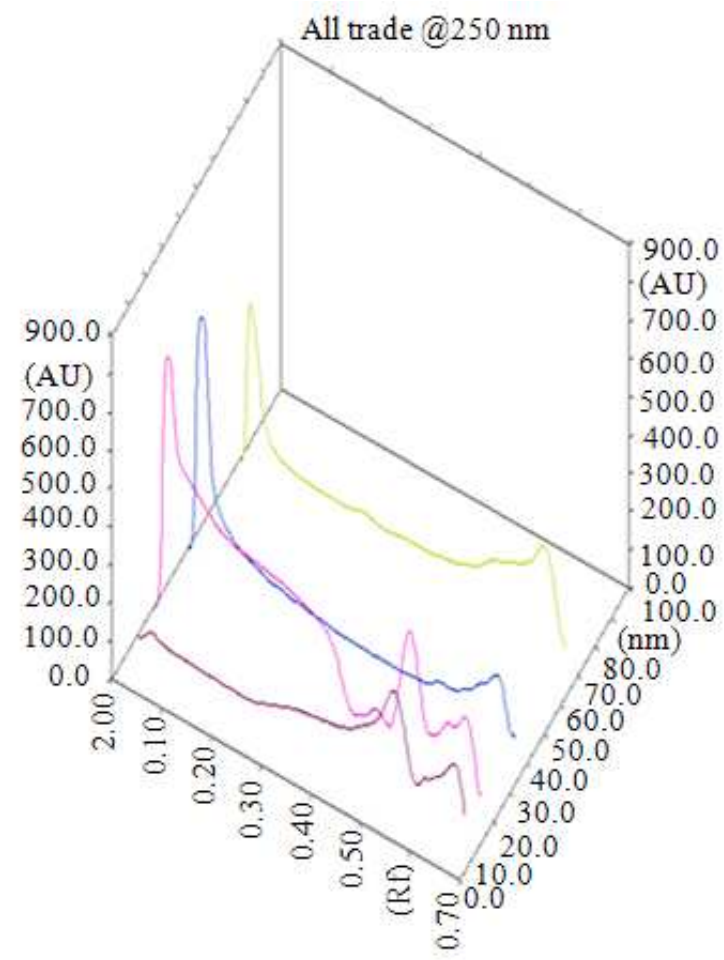

(b)

Fig. 1:HPTLC plate of Gallic Acid and extracts of Ficus benghalensis $3 \mathrm{D}$-image

Suppression of wound breaking strength by dexamethasone was effectively reversed (p-value< $0.05)$ when treated along with aqueous and ethanolic extract of Ficus benghalensis $100 \mathrm{mg} \mathrm{kg}^{-1}$ extract as shown in Table 1 (Table 6 and Fig. 5).

Excision wound model: In excision wound model reversal effect was observed with the extract treated animals which showed significant decrease (p-value $<0.05$ ) in epithelization period (Table 2) and significant increase in percentage wound contraction as compared to dexamethasone alone.

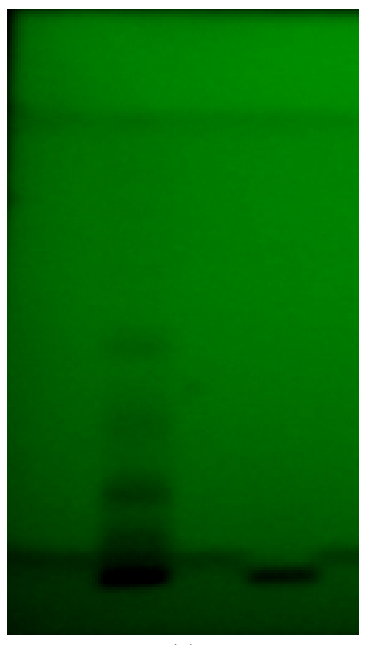

(a)

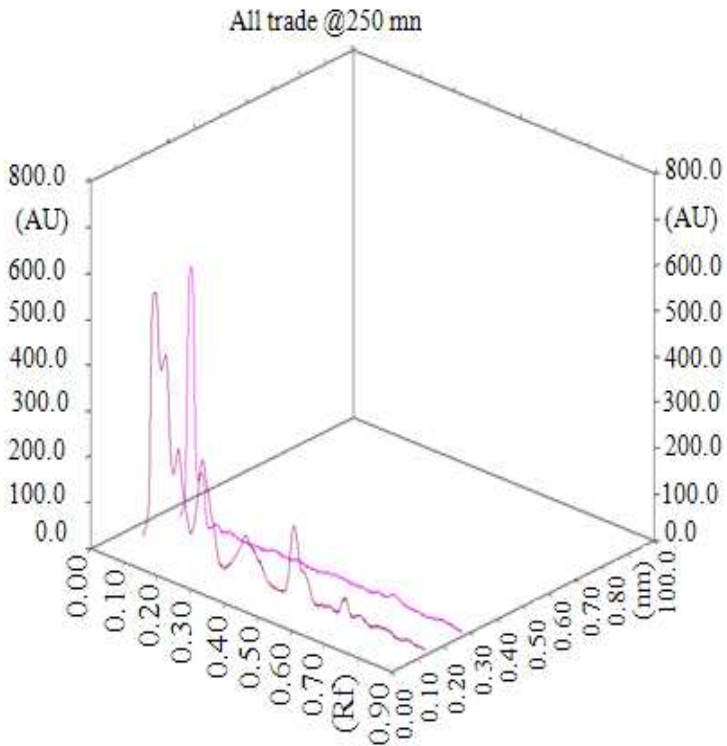

(b)

Fig. 2: HPTLC plate of extracts of Ficus benghalensis 3 D- image

Table 6: Breaking Strength in 10 day old Incision Model

\begin{tabular}{llll}
\hline Groups & Breaking strength (skin) \\
\hline Control (Simple Saline) & $261.5 \pm 4.808$ \\
Dexamethasone & $178.0 \pm 5.373$ & \\
F.B. AQ + Dexamethasone & $252.0 \pm 4.211^{* * *}$ & \\
F.B. ETH + Dexamethasone & $205.5 \pm 4.985^{* * *}$ & \\
\hline$* * *: \quad(\mathrm{p}<0.05)$, values are in mean \pm SE compared with \\
dexamethasone group
\end{tabular}

In dexamethasone alone treated group significant increase ( $p$-value $<0.05$ ) in epithelisation period and decrease in percentage wound contraction were observed when compared to control (Table 7, Fig. 6a and b). 
Am. J. Pharm. \& Toxicol., 6 (2): 68-75, 2011

Table 7: Percentage of wound contraction and epithelialization period in excision model

\begin{tabular}{|c|c|c|c|c|c|c|}
\hline \multirow[b]{2}{*}{ Groups } & \multicolumn{5}{|c|}{$\%$ Wound contraction in days } & \multirow{2}{*}{$\begin{array}{l}\text { Period of } \\
\text { Epithelialization (Days) }\end{array}$} \\
\hline & Day 2 & Day 4 & Day 8 & Day 12 & Day 16 & \\
\hline Control (Simple Saline) & $5.0 \pm 0.87$ & $20.5 \pm 0.24$ & $50.0 \pm 0.23$ & $60.2 \pm 0.54$ & $70.8 \pm 0.32$ & $21.0 \pm 0.6146$ \\
\hline Dexamethasone & $2.0 \pm 1.23$ & $10 \pm 1.54$ & $30.5 \pm 1.67$ & $40.2 \pm 1.23$ & $50.0 \pm 0.23$ & $22.83 \pm 0.2582$ \\
\hline FB.AQ.Extract+ Dexamethasone & $10.0 \pm 0.12$ & $30.0 \pm 0.21 * * *$ & $60.0 \pm 0.65 * * *$ & $73.0 \pm 0.13 * * *$ & $90.0 \pm 0.00 * * *$ & $19.16 \pm 0.4216^{* * *}$ \\
\hline FB. Eth. Extract +Dexamethasone & $8.0 \pm 0.12$ & $25.5 \pm 2.21 * * *$ & $55.5 \pm 1.26^{* * *}$ & $70.0 \pm 2.32 * * *$ & $80.0 \pm 1.32 * * *$ & $20.0 \pm 0.4773 * * *$ \\
\hline
\end{tabular}

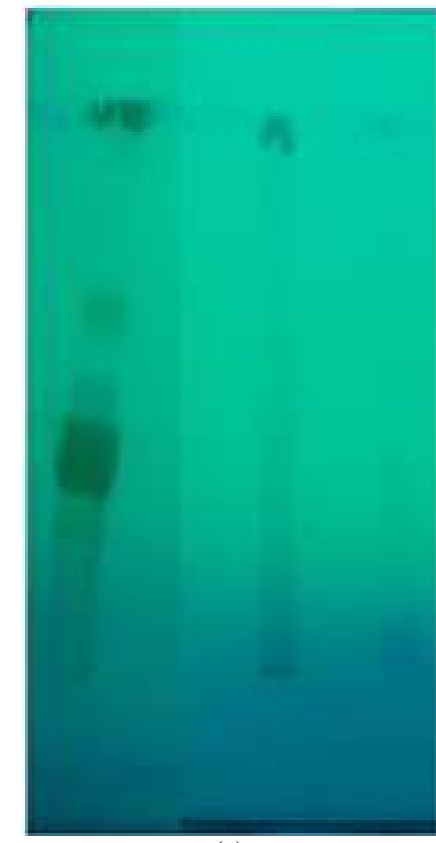

(a)

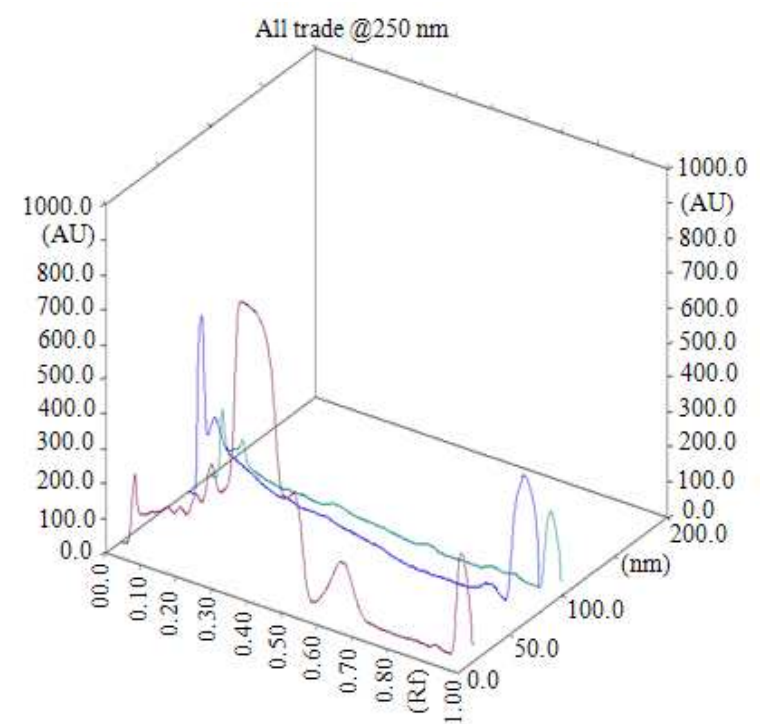

(b)

Fig. 3: HPTLC plate of extracts of Ficus benghalensis 3 D- image

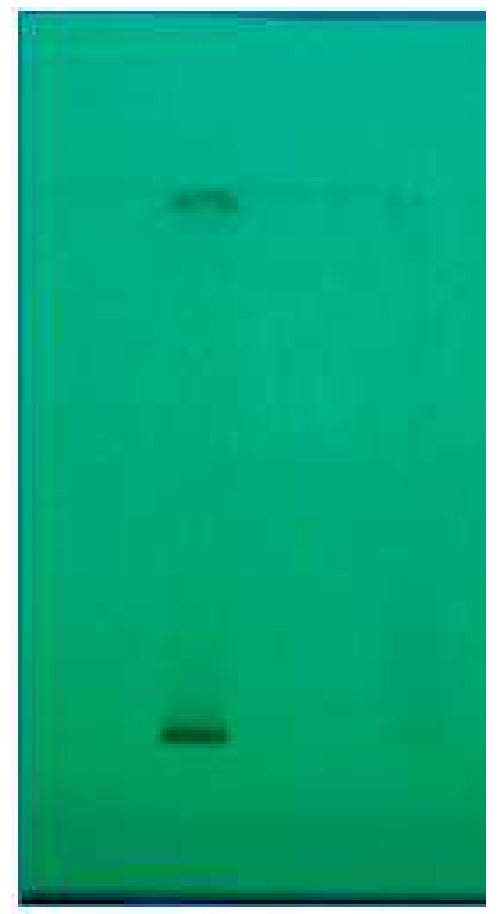

(a)

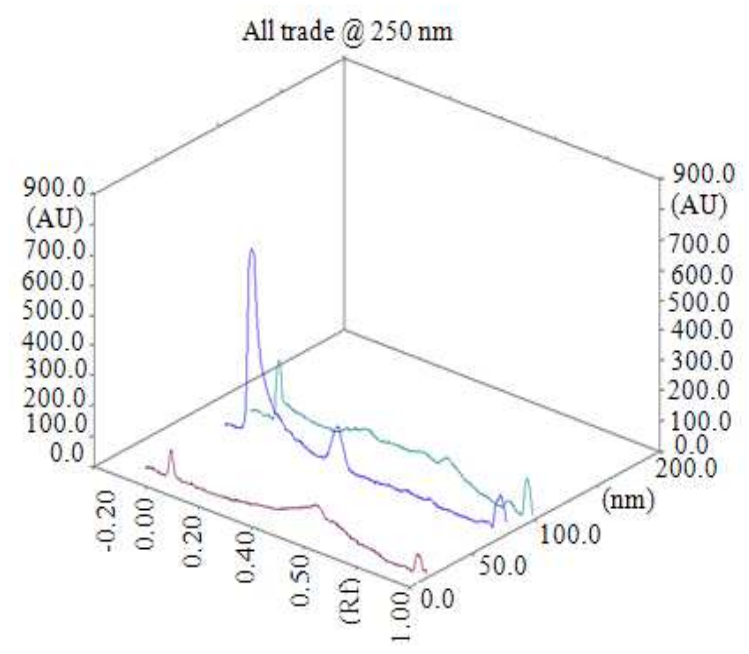

Fig. 4: HPTLC plate of extracts of Ficus benghalensis $3 \mathrm{D}$ - image 


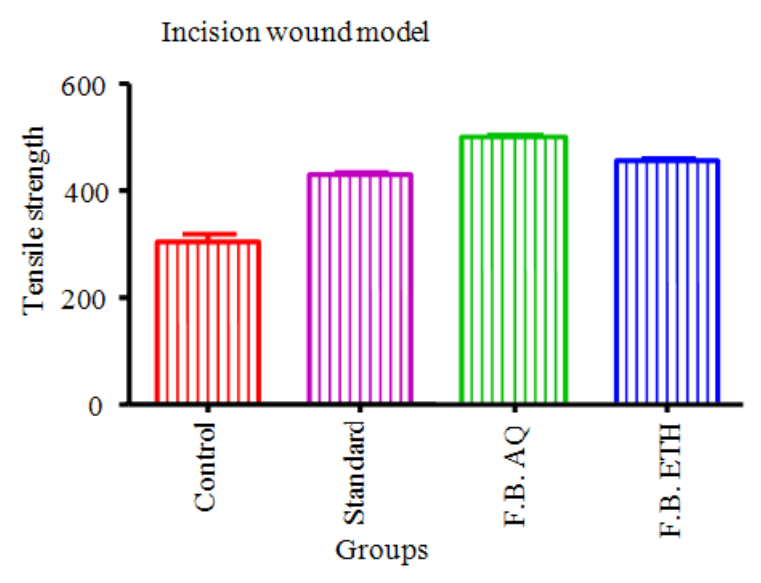

Fig. 5: Incision wound model

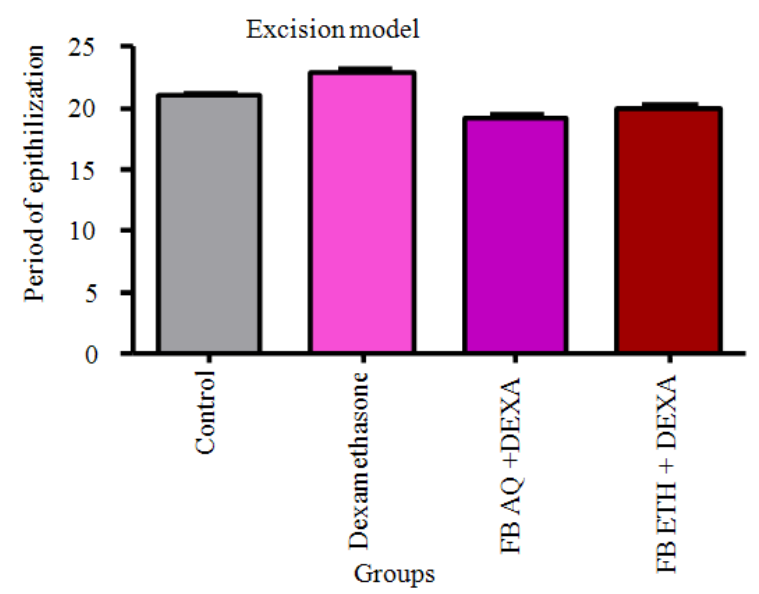

(a)

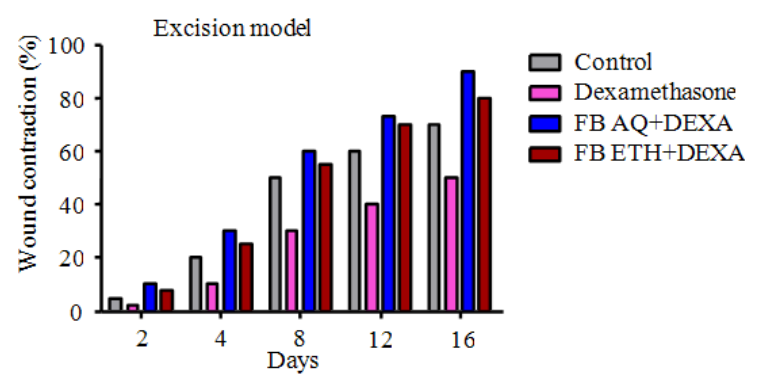

(b)

Fig. 6: Excision wound Model (a) Period of epithelialization in days (b) Percentage wound contraction in days

\section{DISCUSSION}

The complex process of healing involves various phenomena like wound contraction, granuloma formation, collagen maturation etc. The contribution for healing of such processes depends on the type of wound. Wound contraction plays a significant role in healing of excision wound while granuloma formation plays a role in healing of sutured incision. The results of the present study clearly demonstrate that the aqueous and ethanolic extract of Ficus benghalensis possess a definite reversal action in the steroid depressed wound healing. An increase in wound breaking strength of treated wounds may be due to increase in collagen concentration and stabilization of collagen fibres. In recent years oxidative stress has been implicated in a variety of degenerative process and disease. These include acute and chronic inflammatory conditions such as wound healing17. Recent studies with other plant extracts have shown that phytochemical constituents like flavanoids (Tsuchiya et al., 1996), alkaloids (Ansel et al., 1999), saponins (Mukherjee, 2002) and tannins (Rane and Mengi, 2003) are known to promote the wound-healing process. The study reveals that both aqueous and ethanolic extracts treated groups possesses good wound healing properties which may be attributed to the individual or combined action of phytoconstituents like, flavanoids, alkaloids, saponins and tannins present in it. However, from the study it was evident that aqueous extract was having more potential to antagonize the dexamethasone suppressant action. Ethanolic extract was also effective comparable to that of control group. Hence there is need to do research in detail for formulation and development.

\section{CONCLUSION}

In conclusion, the results of this study indicated that roots of Ficus benghalensis reverses dexamethasone depressed wound healing in both the wound models.

\section{ACKNOWLEDGMENT}

This study was supported by Vidyabharti Trust College of Pharmacy, Surat. The authors are thankful to the Managing Trustee for providing the necessary infrastructure to carry out the work successfully.

\section{REFERENCES}

Achrekar, S., G.S. Kaklaji, M.S. Pote and S.M. Kelkar. 1991. Hypoglycemic activity of Eugenia jambolana and Ficus bengalensis: mechanism of action. In vivo, 5: 143-147.

Aiyer, K.N., 1960. Pharmacognosy of Ayurvedic Drugs. 1st Edn., University of Kerala, Kerala, pp: 112. 
Amorin, A.D., H.R. Borba, J.P. Carauta, D. Lopes and M.A. Kaplan, 1999. Anthelmintic activity of the latex of Ficus species. J. Ethnopharm., 64: 255-8. DOI: 10.1016/S0378-8741(98)00139-1

Ansel, H.C., L.V. Allen and N.G. Popovich, 1999. Pharmaceutical Dosage forms and Drug Delivery Systems. 7th Edn., Lippincott-Williams and Wilkins, Philadelphia, ISBN: 0683305727, pp: 595.

Augusti, K.T., 1975. Hypoglycaemic action of bengalenoside, a glucoside isolated from Ficus bengalensis Linn, in normal and alloxan diabetic rabbits. Indian J. Physiol. Pharmacol., 19: 218-220. PMID: 1223001

Augusti, K.T., R.S. Daniel, S. Cherian, C.G. Sheela and C.R. Nair, 1994. Effect of leucopelargonin derivative from Ficus bengalensis Linn. on diabetic dogs. Indian J. Med. Res., 99: 82-86. PMID: 8005644

CSIR, 1952. The Wealth of India: A Dictionary of Indian Raw Materials and Industrial Products. 1st Edn., Publications \& Information Directorate, New Delhi, pp: 24.

Daniel, R.S., B.C. Mathew, K.S. Devi and K.T. Augusti, 1998. Antioxidant effect of two flavonoids from the bark of Ficus bengalensis Linn in hyperlipidemic rats. Indian J. Exp. Biol., 36: 902-906. PMID: 9854431

Deshmukh, V.K., D.S. Shrotri and R. Aiman, 1960. Isolation of a hypoglycemic principle from the bark of Ficus bengalensis Linn. A preliminary note. Ind. J. Physiol. Pharmacol., 4: 182-185. PMID: 13722174

Gabhe, S.Y., P.A. Tatke and T.A. Khan, 2006. Evaluation of the immunomodulatory activity of the methanol extract of Ficus benghalensis roots in rats. Indian J. Pharmacol, 38: 271-5. DOI: 10.4103/0253-7613.27024

Ghosh, M.N., 1971. Fundamentals of Experimental Pharmacology. 1st Edn., Scientific Book Agency, Calcutta, pp: 144.

Gras, M.P., F. Verrecchia, J. Uitto and A. Mauviel, 2001. Downregulation of human type VII collagen (COL7A1) promoter activity by dexamethasone Identification of a glucocorticoid receptor binding region. Exp. Dematol., 10: 28-34. DOI: 10.1034/j.1600-0625.2001.100104.x PMID: 11168577

Husain, A., 1992. Dictionary of Indian Medicinal Plants. 1st Edn., Central Institute of Medicinal and Aromatic Plants, Lucknow, India, pp: 546.

Iqbal, Z., Q.K. Nadeem, M.N. Khan, M.S. Akhtar and F.N. Waraich, 2001. In vitro anthelmintic activity of Allium sativum, zingiber officinale, curcurbita mexicana and ficus religiosa. Int. J. Agric. Biol., 3: 454-257.
Lee, K.H., 1968. Studies on the mechanism of action of salicylates III. Effect of vitamin A on the wound healing retardation action of aspirin. J. Pharm. Sci., 57: 1238-1240. DOI: $10.1002 /$ jps. 2600570736 PMID: 4232621

Mousa, O., P. Vuorela, J. Kiviranta, S.A. Wahab and R. Hiltohen et al., 1994. Bioactivity of certain Egyptian Ficus species. J. Ethnopharm., 41: 71-76. DOI: 10.1016/0378-8741(94)90060-4

Mukherjee, P.K., 2002. Quality Control of Herbal Drugs: An Approach to Evaluation of Botanicals. 1st Edn., Business Horizons, New Delhi, ISBN 8190078844, pp: 800.

Mukherjee, P.K., K. Saha, T. Murugesan, S.C. Mandal and M. Pal et al., 1998. Screening of antidiarrhoeal profile of some plant extracts of a specific region of West Bengal, India. J. Ethnopharm., 60: 85-89. DOI: 10.1016/S03788741(97)00130-X

Oishi, Y., Z.W. Fu, Y. Ohnuki, H. Kato and T. Noguchi, 2002. Molecular basis of the alteration in skin collagen metabolism in response to in vivo dexamethasone treatment: effects on the synthesis of collagen type I and III, collagenase, and tissue inhibitors of metalloproteinases. Bri. J. Dermatol., 147: $\quad 859-868 . \quad$ DOI: $10.1046 /$ j.13652133.2002.04949.x PMID: 12410694

Paul, E.H. and K.H. Thomas, 1968. Effects of cortisone and vitamin a on wound healing. Ann. Surg., 167: 324-328. DOI: 10.1097/00000658-19680300000004 PMID: 5638517 PMCid: 1387060

Pierce, G.F. and T.A. Mustoe, 1995. Pharmacologic enhancement of wound healing. Ann. Rev. Med., 46: 467-481. DOI: 10.1146/annurev.med.46.1.467 PMID: 7598479

Prasad, D. and C.M. Rao, 1995. Wound healing profile of ketorolac, metronidazole and tinidazole administered postsurgically. Ind. J. Exp. Biol., 33: 845-847. PMID: 8786159

Raju, S. and D.R. Kulkarni, 1986. Vitamin A reverses the wound-healing suppressant effect of cyclophosphamide. Ind. J. Pharmacol., 18: 154157.

Rane, M.M. and S.A. Mengi, 2003. Comparative effect of oral administration and topical application of alcoholic extract of Terminalia arjuna bark on incision and excision wounds in rats. Fitoterapia, 74: $\quad 553-558 . \quad$ DOI: $\quad 10.1016 / \mathrm{S} 0367-$ 326X(03)00118-7

Rao, C.M., K.V. Ramesh, K.L. and D.R. Kulkarni. 1991. A simple method to quantify maturation of wound collagen. Ind. J. Exp. Biol., 29: 156-158. PMID: 1869299 
Shrotri, D.S. and R. Aiman, 1960. The relationship of the post-absorptive state to the hypoglycemic action studies on Ficus bengalensis and Ficus glomerata. Ind. J. Med. Res., 48: 16-168. PMID: 14446232

Shukla, R., S. Gupta, J.K. Gambhir, K.M. Prabhu and P.S. Murthy, 2004. Antioxidant effect of aqueous extract of the bark of Ficus bengalensis in hypercholesterolemia rabbits. J. Ethnopharm., 92: 47-51. DOI: 10.1016/j.jep.2004.01.020 PMID: 15099846

Subramanian, P.M. and G.S. Misra, 1978. Chemical constituents of Ficus bengalensis. Polish J. Pharma. Pharma., 30: 559-562. PMID: 740556

Taur, D.J., S.A. Nirmal, R.Y. Patil and M.D. Kharya. 2007. Antistress and antiallergic effects of Ficus bengalensis bark in asthma. Nat. Prod. Res., 21: 1266-1270. DOI: $10.1080 / 14786410701757330$ PMID: 18075889
Tripathi, K.D., 2004. Essentials of Medical Pharmacology. 5th Edn., Jaypee Brothers Medical Publishers, New Delhi, ISBN-10: 8180611876, pp: 890.

Tsuchiya, H., M. Sato, T. Miyazaki, S. Fujiwara and S. Tanigaki et al., 1996. Comparative study on the antibacterial activity of phytochemical flavanones against methicillin-resistant Staphylococcus aureus. J. Ethnopharm., 50: 27-34. DOI: 10.1016/0378-8741(96)85514-0

Warrier, P.K., V.P.K. Nambiar and C. Ramankutty, 1996. Indian Medicinal Plants: A Compendium of 500 Species. 1st Edn., Orient Blackswan, Madras, ISBN: 8125007636, pp: 592. 